\section{Developing a New Fertilizer for the Greenhouse Market}

\author{
John R. Peters ${ }^{1}$
}

Additional index words. marketing, nitrogen, phosphorus, potassium

Summary The development of the Peters 20-1 O-20 water-soluble fertilizer took place at a time when energy and raw materials costs were rising at a double digit rate. Developing a product that could save money for greenhouse crop growers and meet the high performance standards established by the company was the challenge. Product, market, pricing, distribution, and communication issues and strategies were considered in the product development. In 10 years, this new product line became the company's best-selling product line.

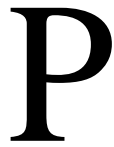

eters Professional 20-20-20 general purpose water-soluble fertilizer has been marketed for $>40$ years, and until 1990, was the top-selling product in the Peters product line. Peters 20-1020 peat-lite took over this top position 10 years after it was first introduced in 1981 . The $2 \mathrm{~N}: 1 \mathrm{P}_{2} \mathrm{O}_{5}$ : $2 \mathrm{~K}_{2} \mathrm{O}$ ratio fertilizers have become the industry standard for successful production of bedding and potted plants and many of the crops produced in the greenhouse today.

The Persian Gulf War caused a rise in the price of gasoline. In 1979, a petroleum shortage affected the chemical industry and energy producers, which resulted in higher gasoline and electricity prices. Eventually, most of the chemicals used to produce water-soluble fertilizers also increased in price. Although some $\mathrm{N}$ products became scarce, the companies supplying monoammonium phosphate were quick to pass along double digit increases every 6 months. Furnace grade monobasic $\mathrm{P}$ was the most expensive component of high quality water-soluble fertilizers. The price of water-soluble fertilizers was being driven upward very quickly by the petroleum shortage.

'Marketing Manager.

Grace-Sierra, P 0. Box 789, Fogelsville, PA 18106-9316.
Another contributing factor was the increasing number of growers using soilless media in greenhouse crop production. Soilless mediadoes not convert ammoniacal $\mathrm{N}$ to nitrate $\mathrm{N}$ as quickly or as effectively as soil-containing media. They also do not have the ability to retain trace elements as does soil-containing media. These factors necessitated the development of a special class of watersoluble fertilizers that had a higher nitrate $\mathrm{N}$ content and higher trace element levels when applied to the growing media.

The customer's needs were changing in the late 1970s. The ability of Grace-Sierra to satisfy those needs with existing products was limited, and the cost to produce and sell those products was increasing rapidly. Timing was right for the development of a new class of products that would address both of these needs.

At Grace-Sierra, our new product development process required that we look at five key areas. We called them the "Big Five." Theywere: 1) the market, 2) the product, 3) the price, 4) distribution, and 5) communication.

First, we examined the market. More than $60 \%$ of the growers in 1980 were producing plants in soilless media. This was a major trend with projections that indicated $\geq 90 \%$ of the U.S. growers would have no soil in their growing media by the end of the 1980s. Grace-Sierra sold products into this market, and we realized the need to adjust the fertilizer product mix to meet this trend.

In examining the product, we had two objectives. First was to reduce our dependence on $P$, and the second was to increase the amount of nitrate $\mathrm{N}$ in the products. Through our analytical laboratories that test soilless media, plant tissue, water, and fertilizer solutions for commercial greenhouses, we were aware that for most plants, reducing applied $\mathrm{P}$ would not affect plant production. Very little $\mathrm{P}$ is used by most plants. We also had become aware of a new source of uncoated ammonium nitrate. Replacing some $\mathrm{P}$ with this new high nitrate $\mathrm{N}$ source would allow us to control costs and improve the performance in soilless media. The resulting 20-10-20 class of products was brought to the market to satisfy the existing needs of both the customer and the company.

Pricing is critical to the success of any product. Long-term pricing of the product in relation to product value to the customer will ensure success. With 20-10-20 fertilizers, we would be able to offer a better and more efficient product for growers who produce plants in soilless media, since the grower would use $78 \mathrm{~g}$ less for $100 \mathrm{gal}$ of a $100 \mathrm{ppm} \mathrm{N}$ solution than for a $15 \% \mathrm{~N}$-containing product. The product was introduced at a price comparable to the 15-16-17 peat-lite.

The distribution considerations were relatively few. These products were added to the current line of Peters Professional water-soluble fertilizers and sold through existing distribution channels.
Potential customers needed to be made aware of this new product and its benefits and features through communication efforts before they could make a purchasing decision. Training meetings were held at key distributor locations where presentations were made about these new product developments. Samples also were made available to those growers who wanted to try the product before committing production areas to a new product.

In summary, when considering new products, one needs to remember that the customer's needs are always changing; satisfying those needs creates opportunities. Always challenge the obvious and remember to define the Big Five of market, product, price, distribution, and communication. 